\title{
„ES GIBT NICHT ZWEI, WIE DER IST”.
}

Om 'n mens se indrukke van prof. Schulze saam te vat, is geen maklike taak nie. Sy invloed op 'n student se literêre smaak, wetenskaplike vorming en lewensbeskouing is so omvangryk, dat ek maar net 'n paar daarvan sal aanroer.

Soos reeds gesê, is prof. Schulze se invloed so omvangryk dat 'n mens eintlik nie weet waar om te begin nie. Ek wil egter begin met iets wat baie onlangs plaasgevind het: Aan die begin van Oktober 1960 het 'n groot aántal Duitse onderwysers vir 'n opknappingskursus in Johannesburg vergader. Gou het dit aan die lig gekom dat ek van Potchefstroom afkomstig is. By hulle tientalle het oud-studente van prof. Schulze my genader, nie om oor vakaangeleenthede te gesels nie, maar om te verneem hoe dit met "hulle Professor" gaan. Sonder enkele uitsondering is daar met lof en waardering gepraat oor prof. H. G. Schulze. Daar kon nie ge- 
noeg gepraat word oor prof. Schulze se uiters deeglike kennis van die Duitse Taal en Lettere nie, sy aangename en vriendelike persoonlikheid, sy fyn humorsin, sy opregtheid en menslikheid.

Toe ek na-graadse studie onder prof. Schulze gedoen het, is die indrukke wat hy op my as voor-graadse student gemaak het, verstewig. As ons daar in sy studeerkamer byeen was, en hy het met soveel gesag en insig oor die een of ander aspek van die Duitse Taal en Lettere gepraat, het ek nog meer besef hoe 'n groot meester prof. Schulze werklik is. Ek het des te meer besef dat ek hier werklik met 'n groot kenner van Duits te doen het. En, hoe wonderlik het prof. Schulze nie daarin geslaag om sy deeglike kennis aan my oor te dra nie. Hy het my 'n deelgenoot daaraan gemaak.

Prof. Schulze het wel deeglik daarin geslaag om by elkeen van sy studente ' $n$ gesonde literêre smaak te ontwikkel. $\mathrm{Hy}$ het hulle geinspireer tot die studie van die hoëre en estetiese in die lewe. Die studie van letterkunde het vir hulle 'n plesier geword en hierdie ryke veld van studie is deur prof. Schulze vir hulle geopen.

Ek onthou nog goed as eerstejaarstudent hoe prof. Schulze hom ten volle in sy stof kon inleef. As hy besig was met die voorlees van gedigte van Goethe, kon selfs die verbystomende trein hom nie steur nie. Dit is voorwaar 'n voorreg om so 'n voordragkunstenaar aan te hoor.

Vir elke student wat die voorreg gehad het om onder prof. Schulze te studeer, staan een karaktertrek van Prof. uit: sy humorsin. Hoe dikwels het ons te midde van ernstige studie, 'n pittige opmerking of grappie aangehoor?

Nieteenstaande Prof. se ontsaglike kennis van die Duitse Taal en Lettere, is hy geensins eensydig in sy ontwikkeling nie. Hy kan met groot gemak en gesag praat van Engelse, Nederlandse en Afrikaanse Letterkunde. Dit was voorwaar vir cns 'n inspirasie om ons ook met ander letterkundes op hoogte te bring.

En nou, Prof., waar u die aftreeleeftyd bereik het, wil ek namens al u oudstudente oor die lengte en breedte van ons land aan $u$ Gods rykste seën toewens. Baie dankie vir alles wat $u$ vir ons beteken het. Ons sal u nie vergeet nie.

So wil ek dan ten slotte my indrukke van prof. Schulze saamvat met die woorde van Schiller waar hy in sy „Wilhelm Tell" sê:

„Es gibt nicht zwei, wie der ist".

A. S. GoUWS. 


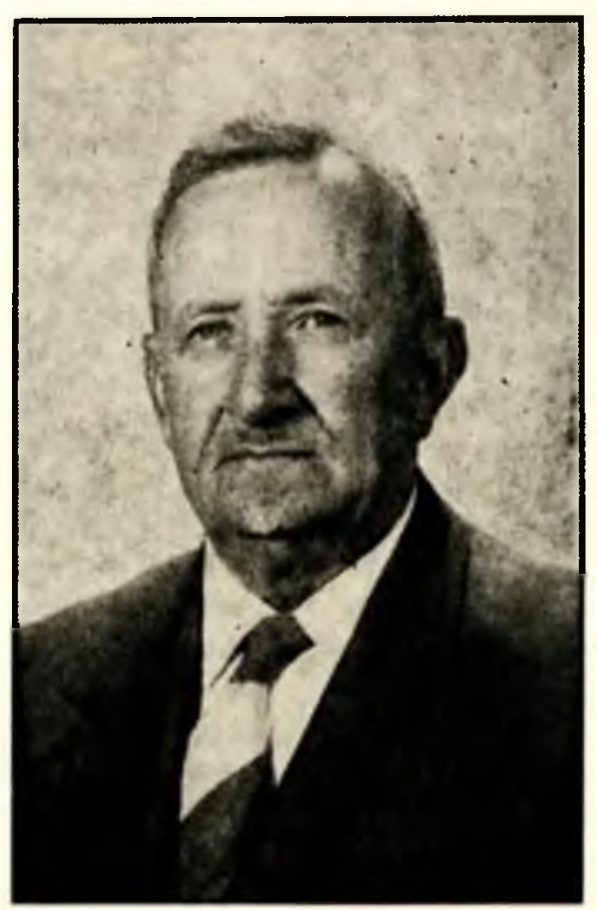

Prof. F. J. Labuschagne 